Наносистели, нанолатеріали, нанотехнології Nanosistemi, Nanomateriali, Nanotehnologii 2020 , т. 18 , № 4 , сс. 969-981 (c) 2020 ІМФ (Інститут металофізики ім. Г. В. Курдюмова НАН України) Надруковано в Україні. Фотокопіювання дозволено тільки відповідно до ліцензії

PACS numbers: 61.80.Ba, 78.20.Ci, 78.67.Sc, 81.07.Pr, 81.16.-c, 82.35.Np, 85.60.Bt

\title{
Synthesis of (Polymer-SnO $)_{2}$ Nanocomposites: Structural and Optical Properties for Flexible Optoelectronics Applications
}

\author{
Ahmed Hashim and Zinah Sattar Hamad \\ University of Babylon, \\ College of Education for Pure Sciences, \\ Department of Physics, \\ Babylon, Iraq
}

In this paper, fabrication of polyvinyl alcohol (PVA)/tin dioxide nanoparticles $\left(\mathrm{SnO}_{2} \mathrm{NPs}\right)$ nanocomposites for UV-shielding is investigated. The structural and optical properties of $\left(\mathrm{PVA}-\mathrm{SnO}_{2}\right)$ nanocomposites are studied. The results of optical properties for $\left(\mathrm{PVA}-\mathrm{SnO}_{2}\right)$ nanocomposites show that the absorbance $(A)$, absorption coefficient $(\alpha)$, extinction coefficient $(K)$, refractive index $(n)$, real $\left(\varepsilon_{1}\right)$ and imaginary $\left(\varepsilon_{2}\right)$ parts of dielectric constant, and optical conductivity $\left(\sigma_{\mathrm{op}}\right)$ of PVA increase, while transmittance $(T)$ and energy band gap $\left(E_{g}\right)$ decrease with an increase in $\mathrm{SnO}_{2}$ nanoparticles' concentration. The results show that $\left(\mathrm{PVA}-\mathrm{SnO}_{2}\right)$ nanocomposites can be used for flexible electronics applications.

У цій роботі досліджено виготовлення нанокомпозитів з наночастинок діоксиду Стануму $\left(\mathrm{SnO}_{2}\right)$ та полівінілового спирту (PVA) для УФ-захисту. Вивчено структурно-оптичні властивості нанокомпозитів $\mathrm{PVA}-\mathrm{SnO}_{2}$. Peзультати щодо оптичних властивостей нанокомпозитів $\mathrm{PVA}-\mathrm{SnO}_{2}$ показують, що спектральна поглинальна здатність $(A)$, коефіцієнт поглинання $(\alpha)$, коефіцієнт екстинкції $(K)$, показник заломлення $(n)$, реальна $\left(\varepsilon_{1}\right)$ й уявна $\left(\varepsilon_{2}\right)$ частини діелектричної константи та оптична провідність $\left(\sigma_{\text {ор }}\right)$ PVA збільшуються, тоді як коефіцієнт пропускання $(T)$ та ширина енергетичної щілини $\left(E_{g}\right)$ зменшуються із збільшенням концентрації наночастинок $\mathrm{SnO}_{2}$. Результати показують, що $\mathrm{PVA}-\mathrm{SnO}_{2}$-нанокомпозити можна використовувати для застосувань у гнучкій електроніці.

Key words: optical properties, tin dioxide, PVA, UV-shielding, nanocomposites.

Ключові слова: оптичні властивості, діоксид Стануму, полівініловий спирт, УФ-екранування, нанокомпозити.

(Received 8 March, 2020; in final version, 1 April, 2020) 


\section{INTRODUCTION}

Protection against ultraviolet radiation is an important issue in modern technological era. The oxidation caused by the action of UV rays can form basis for acute mutilation to both living organisms and materials, e.g., action of photonic energy may produce undesired breakage of chemical structures in non-UV protecting materials, which can be detrimental to living organism. Additionally, skin photoaging might take place under intense ultraviolet light. UV-rays can also cause degradation of the organic molecules including polymers, bleaches, tinctures and semiconductor photocatalysis. UVC range $(100-290 \mathrm{~nm})$ light rays having energy of about $4.43-12.4 \mathrm{eV}$ can cause more serious harm than that of UVB (290-320 nm) and UVA (320-400 nm) light rays possessing energies of about $3.94-4.43 \mathrm{eV}$ and $3.10-3.94 \mathrm{eV}$, respectively. Therefore, it is intensely desired to develop a material, which can block various ranges of ultraviolet rays particularly in the UVC range to minimize the possibility of damage. Such materials can be tailored by reinforcing inorganic fillers into a transparent polymer matrix, so that band gap in the desired region can be achieved which can further help in UV blocking. In order to make practical use of such materials, it is appropriate to use them in the form of either solutions or polymeric films of fine powder. The use of reinforced polymer matrix is advantageous over host material because such composites can be employed as UV protecting shields. The inorganic nanoparticles having capability of cutting the UV absorption can be incorporated in polymer leading to the enhancement in their properties so that their utility in day-to-day life is dramatically enhanced [1].

The production of novel polymeric nanocomposites have been widely studied by the current applications on nanosize inorganic fillers in the food packaging field, barrier applications, sensors, antimicrobial, conductive, coatings, antiballistic products and other materials. The characteristics and properties of the nanocomposites are influenced by the type of filler used as well as by the polymeric matrix. The applications encompass several areas such as electronic, medicine, military, aerospace, marine, and vehicles [2]. Polymer-matrix composites (denoted as PMCs) have consistently been of interest for decades, because they possess markedly improved mechanical properties (tensile modulus and strength), thermal stability, chemical resistance, flame retardation and barrier resistance as compared with pure polymers. It is well known that the interfacial effect between nanoparticles and the polymer matrix greatly affect the properties of nanocomposites. It is generally believed that the dispersion of fillers in the polymer matrix is an important issue for improving the properties of nanocomposites [3].

The optical properties of doped polymers have been attracted considerable attention because of the range of technological applications 
that include solar cells, coatings, light emitting diodes, sensors and electrochemical cells. The attention of researchers has drawn to study effect of doping on the optical properties of solid polymer electrolytes be tailored to a specific requirement by the addition of suitable dopant substances.

Measurements and determination the optical absorption and especially the absorption edge present a useful method for the investigation of optically induced transition and for getting information about the band structure [4]. Polyvinyl alcohol (PVA) is a polymer with carbon chain backbone attached with hydroxyl groups. These $\mathrm{OH}$ groups can be a source of hydrogen bonding and hence assist in the formation of polymer blends. PVA is non-toxic, water-soluble synthetic polymer, which is widely used in the polymer blends due to its good physical and chemical properties, excellent film forming characteristics, emulsifying capability, non-carcinogenic, biodegradable and biocompatible qualities. These unique characteristics enable it for its applicability in pharmaceutical fields, drug-coating agents, material for surgical structures and cosmetic industries [5].

The new production of composites contain carbides [6-12], metal and oxides [13-25], ionic materials, and biomaterials [26-28]. The nanocomposites have different modern applications such as piezoelectric and pressure sensors [29], antibacterial, etc. [30]. Tin oxide is widely used and studied $n$-type semiconductor with wide band gap and crystalline structure. Studies have been carried out on tin oxide based gas sensors, dye sensitized solar cells optical devices, optoelectronic devices and hybrid microelectronic devices. The compound has lately also been identified as possible electrode material for lithium cells and photo catalysis. With properties such as transparency in semiconductivity, it is an oxide of great interest from the technological point of view for white pigment for conducting coatings. Tin oxide nanoparticles are synthesized through different chemical roots such as co-precipitation, hydrothermal, sol-gel, sonochemical polymer, precursor method among others [31]. Tin dioxide is an $n$-type semiconductor oxide with a wide energy gap.

Tin dioxide $\left(\mathrm{SnO}_{2}\right)$ has attracted much attention for its various applications, such as catalyst, catalytic support, biomedical, pharmaceutical, gas sensor, rechargeable Li battery and optical electronic device. However, the catalytic activity of gold supported on tin dioxide is gearing up attention in recent years. It is observed that these nanocomposites showed excellent catalytic property of $\mathrm{CO}$ oxidation at low temperatures [32].

\section{MATERIALS AND METHODS}

The (polyvinyl alcohol and tin dioxide) nanocomposites were fabricated 
by using casting technique. The PVA/ $\mathrm{SnO}_{2}$ nanocomposites were prepared with different concentrations of PVA and $\mathrm{SnO}_{2}$ nanoparticles where dissolve $1 \mathrm{gm}$ of PVA in $20 \mathrm{ml}$ of distilled water by using magnetic stirrer to mix the polymers for 1 hour to obtain more homogeneous solution. The $\mathrm{SnO}_{2}$ nanoparticles were added to the PVA solution with concentrations of 2, 4 and 6 wt.\%. The optical properties of PVA/ $\mathrm{SnO}_{2}$ nanocomposites are measured by using the double beam spectrophotometer (Shimadzu, UV-1800 $\mathrm{A}$ ) in wavelength $200-800 \mathrm{~nm}$.

The absorption coefficient $(\alpha)$ of nanocomposites is given by the equation [33]:

$$
\alpha=2.303 A / t,
$$

where $A$ is the absorbance of sample, and $t$-the sample thickness in $\mathrm{cm}$. The non-direct transition model for amorphous semiconductors was determined by following equation [34, 35]:

$$
\alpha h \mathrm{v}=B\left(h \mathrm{v}-E_{g}\right)^{r},
$$

where $B$ is a constant, $h v$ is the photon energy; $E_{g}$ is the optical energy band gap; $r=2$ or 3 for allowed and forbidden indirect transitions.

The extinction coefficient $(k)$ of $\mathrm{PVA} / \mathrm{SnO}_{2}$ nanocomposites is given by using the following equation [36, 37]:

$$
K=\alpha \lambda /(4 \pi) .
$$

The refractive index $(n)$ of $\mathrm{PVA} / \mathrm{SnO}_{2}$ nanocomposites can be calculated by using the following equation [38, 39]:

$$
n=\left(1+R^{1 / 2}\right) /\left(1-R^{1 / 2}\right) .
$$

The real and imaginary parts of dielectric constant $\left(\varepsilon_{1}\right.$ and $\left.\varepsilon_{2}\right)$ were calculated by using equations $[40,41]$ :

$$
\begin{gathered}
\varepsilon_{1}=n^{2}-k^{2}, \\
\varepsilon_{2}=2 n k .
\end{gathered}
$$

The optical conductivity was calculated by using the equation [42]:

$$
\sigma=\alpha n c /(4 \pi) .
$$

\section{RESULTS AND DISCUSSION}

The optical absorbance of pure PVA and $\mathrm{SnO}_{2}-\mathrm{PVA}$ nanocomposites is 
presented in Fig. 1. The pure PVA film is highly transparent in nature because its spectrum does not display any peak in the visible region but it displays a peak in ultraviolet region of electromagnetic spectrum, so it can be used as a polarizer [43], flexible electronic applications and UV-shielding.

By increasing the loadings of $\mathrm{SnO}_{2}$ nanoparticles, the transparency of PVA was further decreased as shown in Fig. 2. The pure PVA spec-

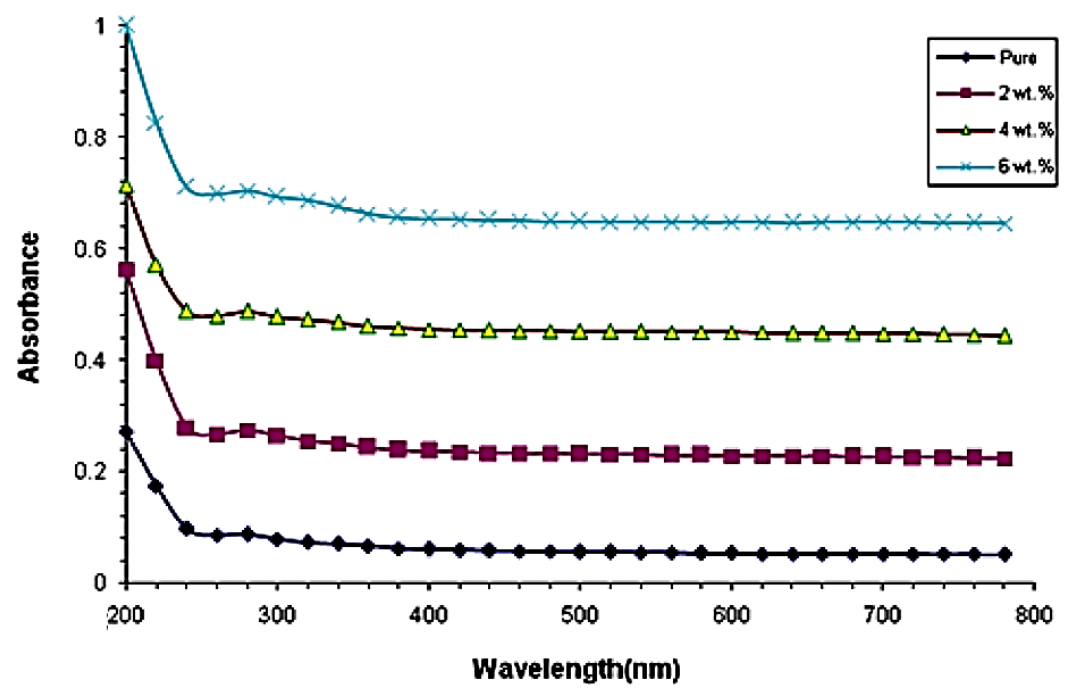

Fig. 1. Optical absorbance of pure PVA and $\mathrm{SnO}_{2}-\mathrm{PVA}$ nanocomposites.

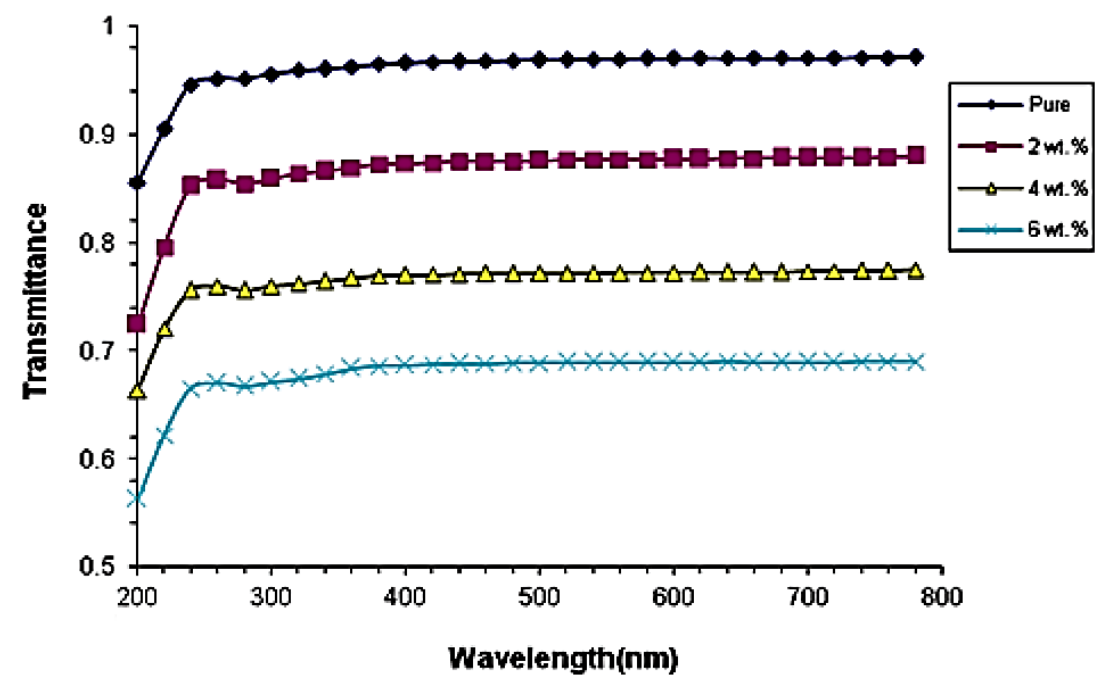

Fig. 2. Transmittance spectra of pure PVA and $\mathrm{SnO}_{2}-\mathrm{PVA}$ nanocomposites. 

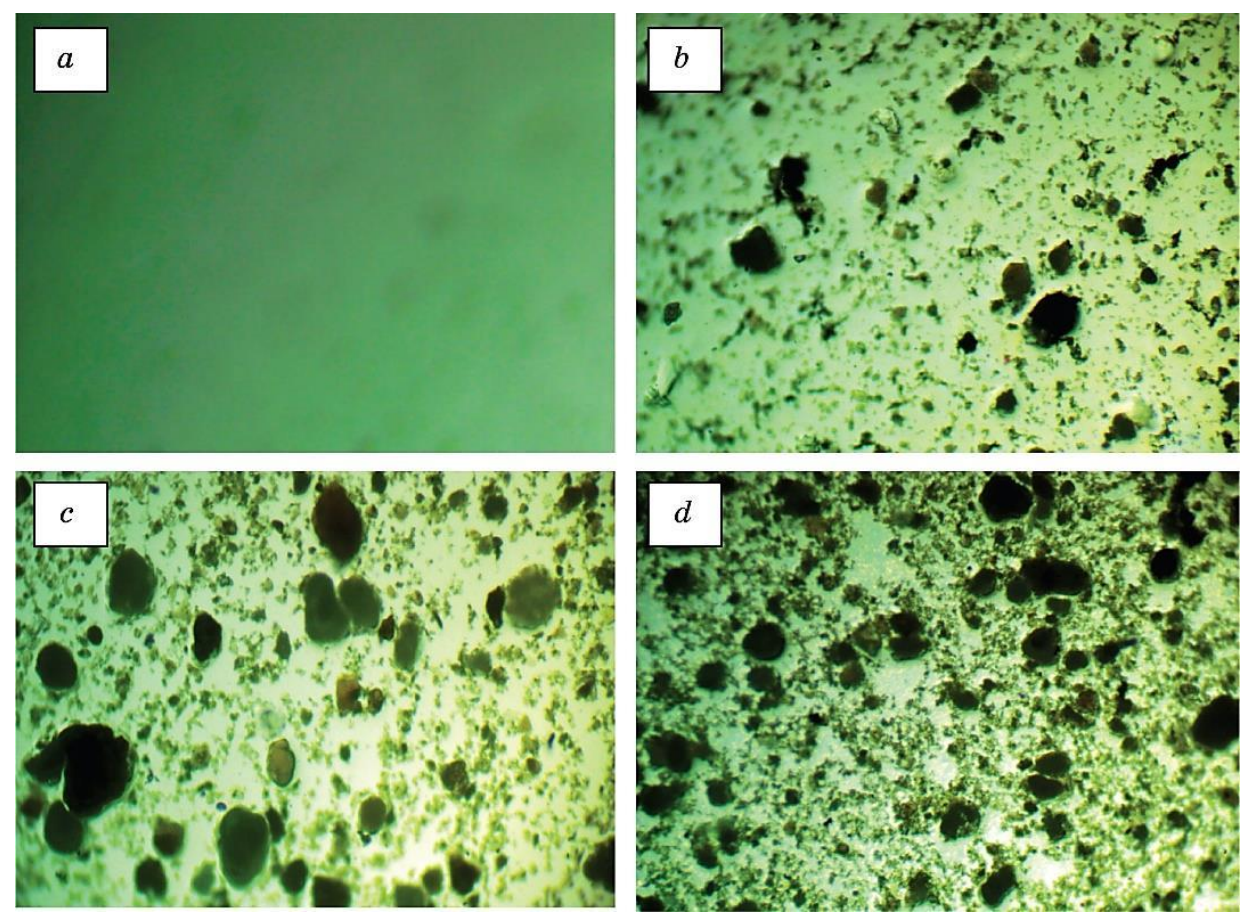

Fig. 3. Microscopy images $(\times 10)$ for $\left(\mathrm{PVA}-\mathrm{SnO}_{2}\right)$ nanocomposites: $(a)$ for PVA; (b) for 2 wt. $\% \mathrm{SnO}_{2}$; (c) for 4 wt. $\% \mathrm{SnO}_{2} ;(d)$ for 6 wt. $\% \mathrm{SnO}_{2}$.

trum shows an absorbance peak at $200 \mathrm{~nm}$ due to $(\mathrm{CH}=\mathrm{CH})_{4}-\mathrm{CO}-$ structure. It also displays two other absorbance peaks at 280 and 330 $\mathrm{nm}$ due to $\pi-\pi^{*}$ and $\nu-\pi^{*}$ transitions, respectively [43]. The absorbance of $\left(\mathrm{SnO}_{2}-\mathrm{PVA}\right)$ nanocomposites is increased as well as the transmittance with an increase in $\mathrm{SnO}_{2}$ nanoparticles' concentration. This is due to increase the number of free electrons, which absorb the incident light [44], as shown in Fig. 3.

The variation of absorption coefficient of $\mathrm{SnO}_{2}$-PVA nanocomposites with the photon energy for different concentrations of tin dioxide nanoparticles is shown in Fig. 4. The absorption coefficient of $\mathrm{SnO}_{2}-$ PVA nanocomposites is increased with the increase in $\mathrm{SnO}_{2}$ nanoparticles' concentration that is attributed to increase the number of carries charges in nanocomposites. The absorption coefficient values are less than $10^{4} \mathrm{~cm}^{-1}$; this means that the $\mathrm{SnO}_{2}$-PVA nanocomposites have indirect energy gap, which is shown in Figs. 5, 6 for allowed indirect and forbidden indirect transition of nanocomposites, respectively. The energy band gap of PVA is decreased with the increase in tin dioxide nanoparticles' concentration; this is due to increase of the localized level in energy band gap [45]. 
The refractive index and extinction coefficient of $\mathrm{SnO}_{2}-\mathrm{PVA}$ nanocomposites are shown in Figs. 7, 8.

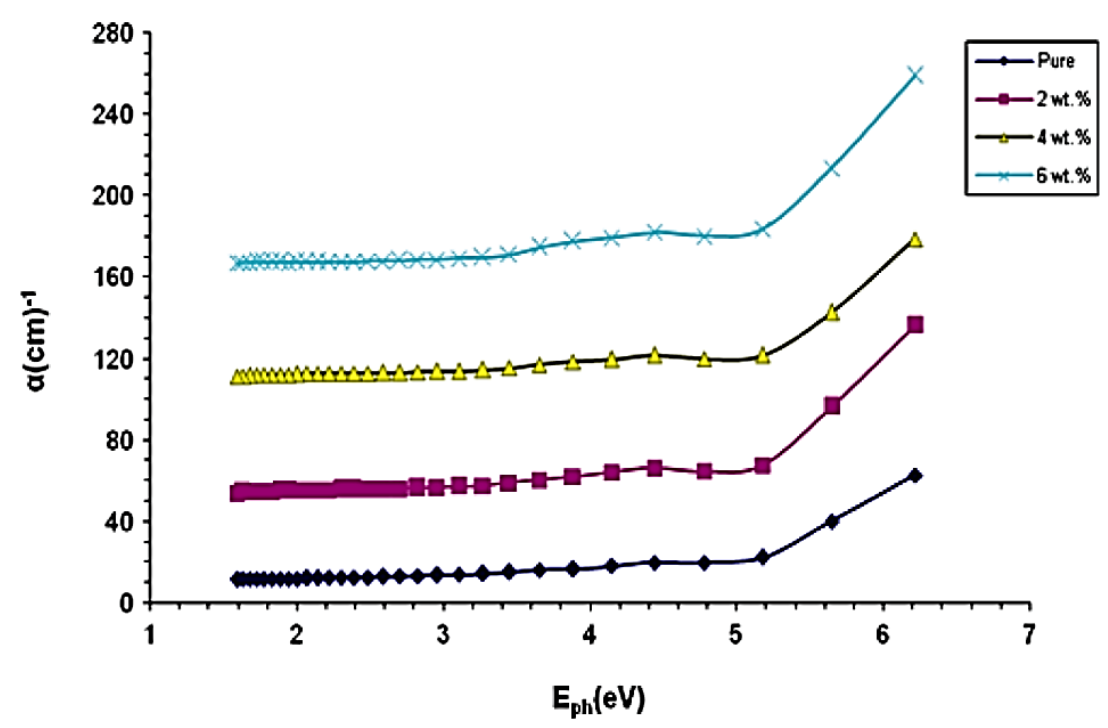

Fig. 4. Variation of absorption coefficient of $\mathrm{SnO}_{2}-\mathrm{PVA}$ nanocomposites with the photon energy for different concentrations of tin dioxide nanoparticles.

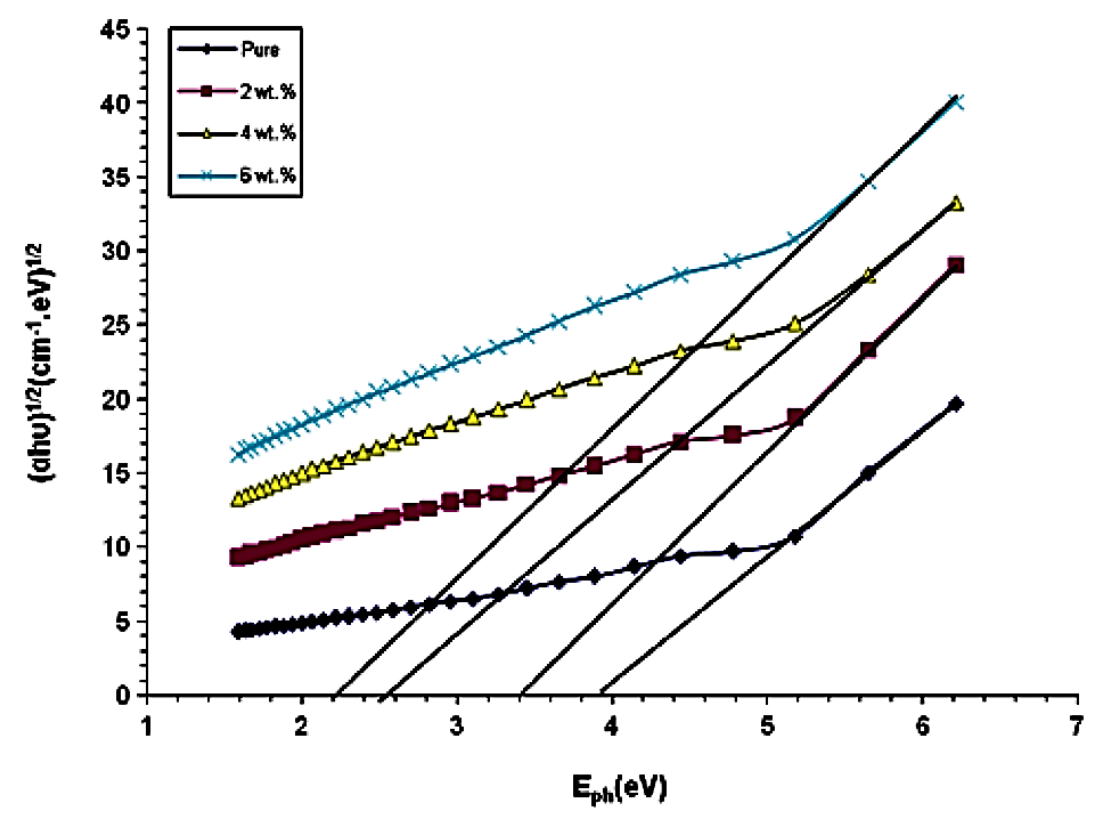

Fig. 5. Energy band gap for allowed indirect transition of nanocomposites. 


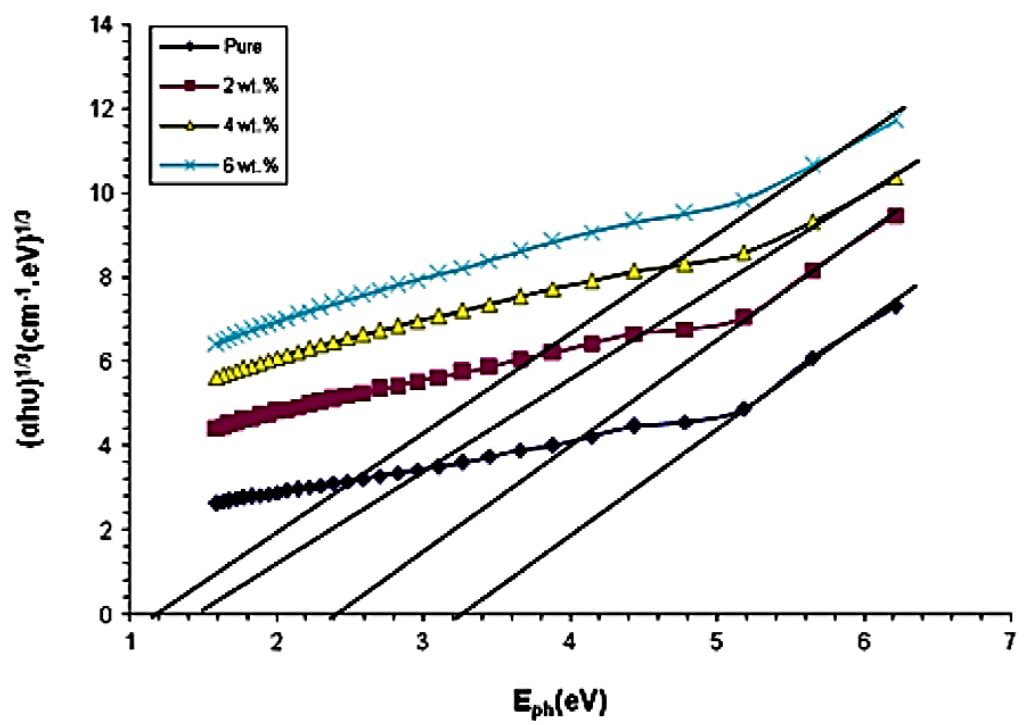

Fig. 6. Energy band gap for forbidden indirect transition of nanocomposites.

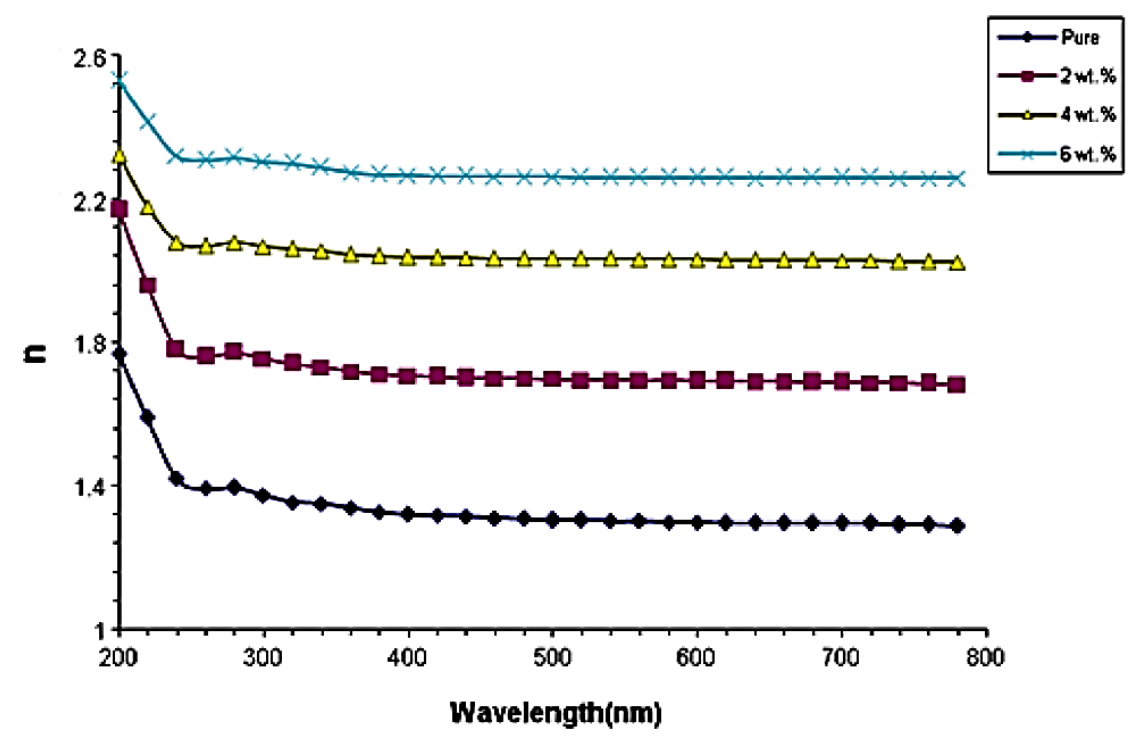

Fig. 7. Refractive index of $\mathrm{SnO}_{2}-\mathrm{PVA}$ nanocomposites.

The figures show that the refractive index and extinction coefficient increase with the concentration of $\mathrm{SnO}_{2}$ nanoparticles, which are related to the increase in the density of nanocomposite that lead to the scattering and the number of charge carriers as a result of the increase 
in the reflectance and absorption coefficient [46].

The real and imaginary parts of the dielectric constant of the $\mathrm{SnO}_{2}-$ PVA nanocomposites shown in Figs. 9 and 10.

The dielectric constant of compound $(\varepsilon)$ is divided into two parts: real $\left(\varepsilon_{1}\right)$ and imaginary $\left(\varepsilon_{2}\right)$ ones. The real parts of dielectric constant is

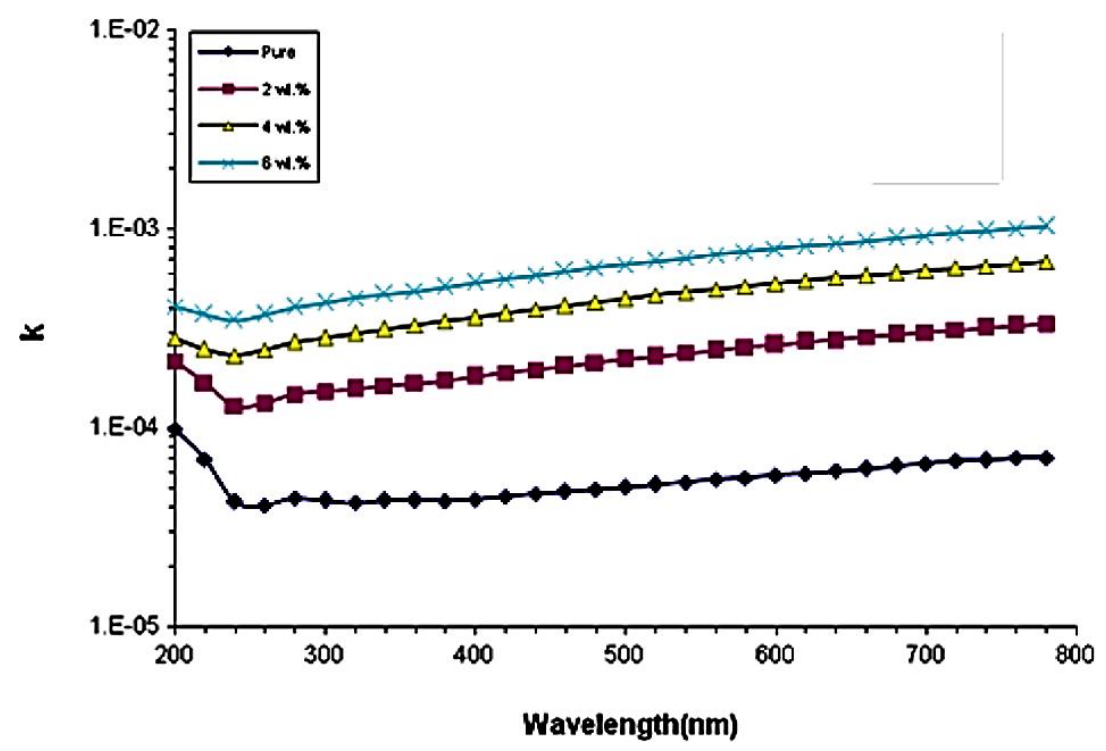

Fig. 8. Extinction coefficient of $\mathrm{SnO}_{2}-\mathrm{PVA}$ nanocomposites.

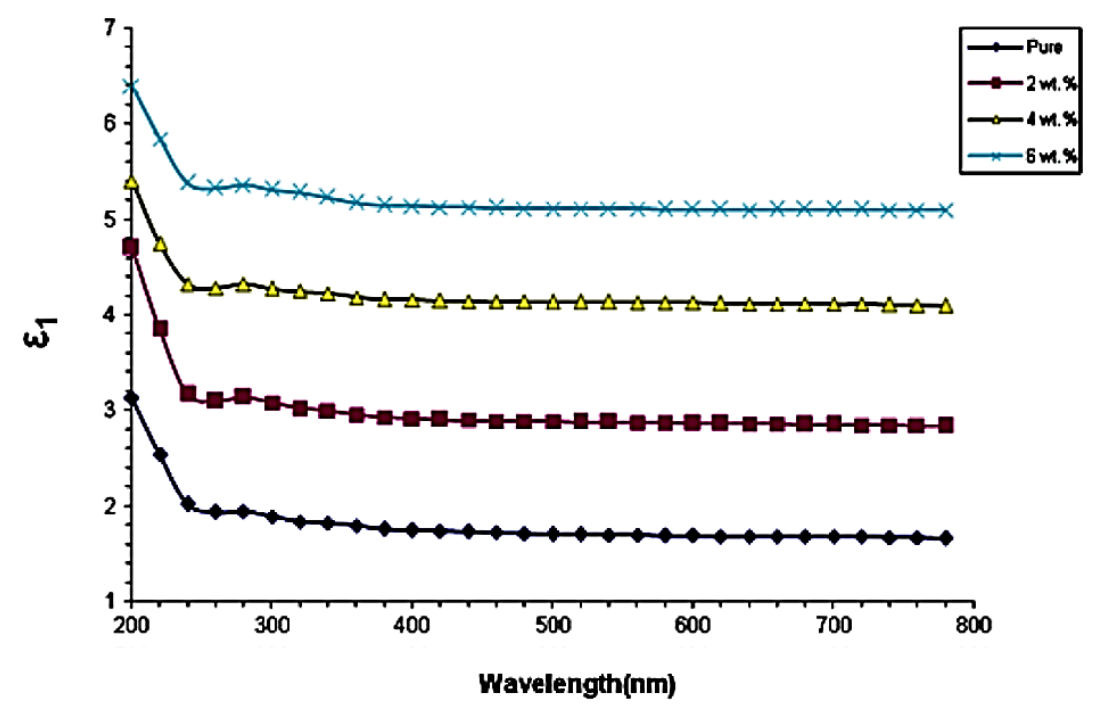

Fig. 9. Real part of the dielectric constant of the $\mathrm{SnO}_{2}-\mathrm{PVA}$ nanocomposites. 
associated with the term that shows how much will slow down the speed of light in the material and the imaginary parts shows how a dielectric absorbs energy from an electric field due to dipole motion [47].

The optical conductivity of the $\mathrm{SnO}_{2}$-PVA nanocomposites with

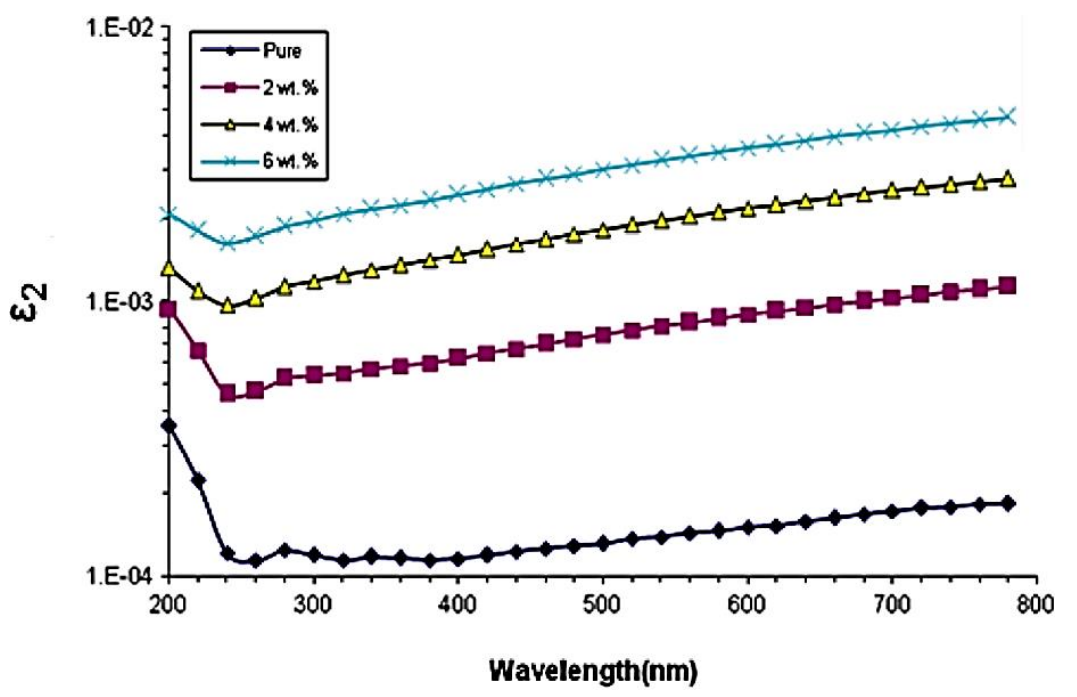

Fig. 10. Imaginary part of the dielectric constant of the $\mathrm{SnO}_{2}-\mathrm{PVA}$ nanocomposites.

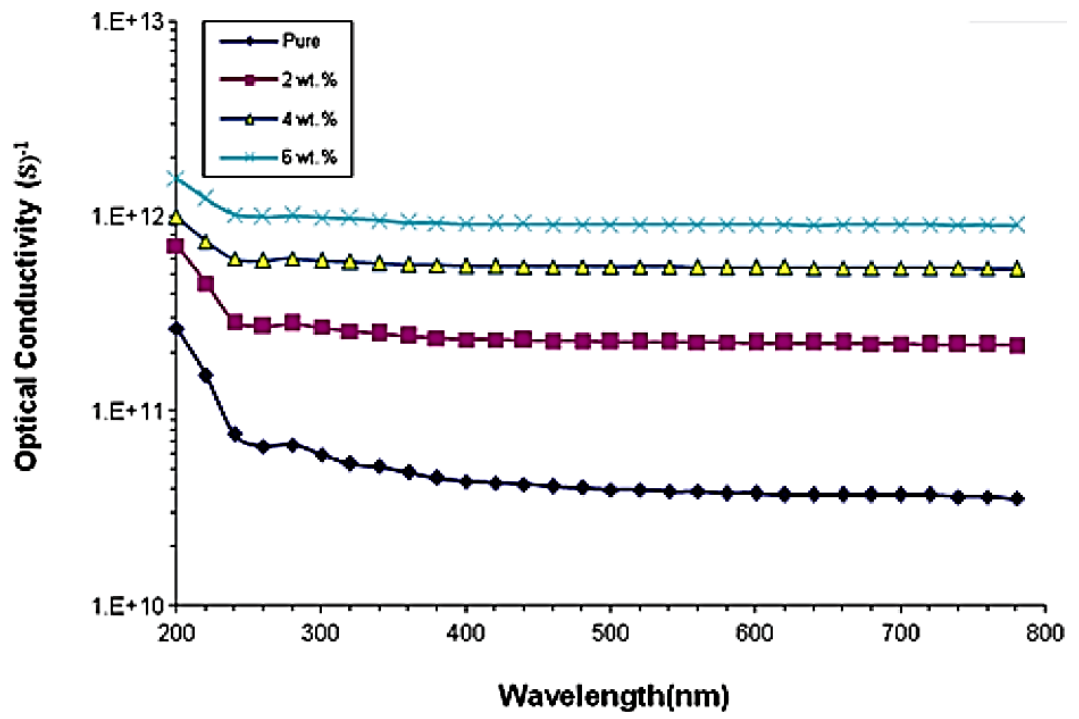

Fig. 11. Optical conductivity of the $\mathrm{SnO}_{2}$-PVA nanocomposites with wavelength. 
wavelength is shown in Fig. 11.

The term 'optical conductivity' means the electrical conductivity, which is resulted from the movement of the charge carriers due to alternating electric field of the incident electromagnetic waves. From this figure, it is noticed that the optical conductivity of PVA increases with increasing $\mathrm{SnO}_{2}$ nanoparticles. This increase due to creation of new levels in the band gap leads to facilitate the crossing of electrons from the valence band to these local levels to the conduction band; consequently, the band gap decreases and the conductivity increase [48$52]$.

\section{CONCLUSION}

The optical absorbance of pure PVA increases, while the transmittance decreases with increase of $\mathrm{SnO}_{2}$ nanoparticles' concentration. The absorbance of $\mathrm{SnO}_{2}$-PVA nanocomposites have higher values at UV region, which can be used for flexible electronics applications and flexible UV-shielding. The optical energy band gap of polyvinyl alcohol decreases with increase in $\mathrm{SnO}_{2}$ nanoparticles' concentration. The absorption coefficient, extinction coefficient, refractive index, real and imaginary parts of dielectric constant and optical conductivity of PVA increase with increase in $\mathrm{SnO}_{2}$ nanoparticles' concentration.

\section{REFERENCES}

1. A. Gautam, A. S. Kshirsagar, S. Banerjee, V. V. Dhapte, and P. K. Khanna, Journal of Materials Science \& Nanotechnology, 4, No. 1 (2016).

2. F. J. Tommasini, L. da Cunha Ferreira, L. G. P. Tienne, V. de Oliveira Aguiar, M. H. P. da Silva, L. F. da Mota Rocha, and M. de Fátima Vieira Marques, Materials Research, 21, No. 6 (2018).

3. Qi-Jie Xu, Shi-Bing Wang, Fang-Fei Chen, Tian-Cong Cai, Xiao-Hong Li, and Zhi-Jun Zhang, Nanomater. Nanotechnol., 6, No. 31 (2016).

4. M. Al-Tweissi, M. A. Tarawneh, and M. Q. Owaidat, J. Nano- Electron. Phys., 10 (2018).

5. T. Siddaiah, P. Ojha, N. O. G. V. R. Kumar, and C. Ramu, Materials Research, 21, No. 5 (2018).

6. $\quad$ A. Hashim and Q. Hadi, Sensor Letters, 15 (2017); doi:10.1166/sl.2017.3892

7. A. Hashim and Z. S. Hamad, J. Nanostruct., 9, No. 2: 340 (2019); doi:10.22052/JNS.2019.02.016

8. H. Ahmed, H. M. Abduljalil, and A. Hashim, Transactions on Electrical and Electronic Materials (2019); https://doi.org/10.1007/s42341-019-00111-z

9. H. Ahmed, H. M. Abduljalil, and A. Hashim, Transactions on Electrical and Electronic Materials (2019); https://doi.org/10.1007/s42341-019-00100-2

10. A. Hashim and Q. Hadi, J. of Materials Science: Materials in Electronics, 29: 11598 (2018); https://doi.org/10.1007/s10854-018-9257-z 
11. F. L. Rashid, S. M. Talib, A. Hadi, and A. Hashim, IOP Conf. Series: Materials Science and Engineering, 454: 012113 (2018); doi:10.1088/1757899X/454/1/012113

12. A. Hadi, F. L. Rashid, H. Q. Hussein, and A. Hashim, IOP Conference Series: Materials Science and Engineering, 518, Iss. 3: 5 (2019); doi:10.1088/1757$899 \mathrm{X} / 518 / 3 / 032059$

13. D. Hassan and A. H. Ah-Yasari, Bulletin of Electrical Engineering and Informatics, 8, Iss. 1 (2019); doi:10.11591/eei.v8i1.1019

14. A. Hashim, M. Ali Habeeb, A. Hadi, Q. M. Jebur, and W. Hadi, Sensor Letters, 15 (2017); doi:10.1166/sl.2018.3935

15. H. Abduljalil, A. Hashim, and A. Jewad, European Journal of Scientific Research, 63, No. 2: 231 (2011).

16. Z. Al-Ramadhan, A. Hashim, and A. J. Kadham Algidsawi, AIP Conference Proceedings, 1400, No. 1 (2011); https://doi.org/10.1063/1.3663109

17. A Hashim and A. Hadi, Ukrainian Journal of Physics, 62, No. 12 (2017); doi:10.15407/ujpe62.12.1050

18. A. Hashim and A. Hadi, Sensor Letters, 15 (2017); doi:10.1166/sl.2017.3910

19. A. Hashim and A. Hadi, Ukrainian Journal of Physics, 63, No. 8 (2018); https://doi.org/10.15407/ujpe63.8.754

20. N. H. Al-Garah, F. L. Rashid, A. Hadi, and A. Hashim, 12 (2018); doi:10.1166/jbns.2018.1538

21. K. H. H. Al-Attiyah, A. Hashim, and S. F. Obaid, Journal of Bionanoscience, 12 (2018); doi:10.1166/jbns.2018.1526

22 A. Hashim and A. Hadi, Sensor Letters, 15 (2017); doi:10.1166/sl.2017.3900

23 A. J. Kadham, D. Hassan, N. Mohammad, and A. Hashim, Bulletin of Electrical Engineering and Informatics, 7, No. 1 (2018); doi:10.11591/eei.v7i1.839

24. F. Ali Jasim, F. Lafta, A. Hashim, M. Ali, and A. G. Hadi, Journal of Engineering and Applied Sciences, 8, No. 5: 140 (2013).

25. A. Hashim and Q. Hadi, Journal of Materials Science: Materials in Electronics, 29: 11598 (2018); https://doi.org/10.1007/s10854-018-9257-z

26. M. Ali Habbeb, A. Hashim, and A.-R. K. Abid Ali, European Journal of Scientific Research, 61, No. 3: 367 (2011).

27. F. Ali Jasim, A. Hashim, A. G. Hadi, F. Lafta, S. R. Salman, and H. Ahmed, Research Journal of Applied Sciences, 8, Iss. 9: 439 (2013).

28. M. Ali Habbeb, A. Hashim, and A.-R. K. Abid Ali, European Journal of Scientific Research, 61, No. 3: 367 (2011).

29. D. Hassan and A. Hashim, Bulletin of Electrical Engineering and Informatics, 7, No. 4 (2018).

30. A. Hashim, I. R. Agool, and K. J. Kadhim, Journal of Bionanoscience, 12, No. 5 (2018); doi:10.1166/jbns.2018.1580

31. L. I. Nadaf, K. S. Venkatesh, M. A. Gadyal, and M. Afzal, IOSR Journal of Applied Chemistry, 9, Iss. 2 (2016).

32. B. Xavier, A. Ramanand, and P. Sagayaraj, Der. Pharma Chemica, 4, No. 4 (2012).

33. S. Hadi, A. Hashim, and A. Jewad, Australian Journal of Basic and Applied Sciences, 5, No. 9: 2192 (2011).

34. A. Hashim, M. A. Habeeb, A. Khalaf, and A. Hadi, Sensor Letters, 15: 589 
(2017); doi:10.1166/sl.2017.3856

35. A. Hashim and A. Jassim, Sensor Letters, 15, No. 12: (2017); doi:10.1166/sl.2018.3915

36. F. L. Rashid, A. Hashim, M. Ali Habeeb, S. R. Salman, H. Ahmed, Journal of Engineering and Applied Sciences, 8, No. 5: 137 (2013).

37. A. Hashim, Y. Al-Khafaji, and A. Hadi, Transactions on Electrical and Electronic Materials (2019); https://doi.org/10.1007/s42341-019-00145-3

38. I. R. Agool, F. S. Mohammed, and A. Hashim, Advances in Environmental Biology, 9, No. 11 (2015).

39. A. Hashim and A. Jassim, Journal of Bionanoscience, 12 (2018); doi:10.1166/jbns.2018.1518

40. A. Hashim, I. R. Agool, and K. J. Kadhim, Journal of Materials Science: Materials in Electronics, 29, Iss. 12: 10369 (2018); https://doi.org/10.1007/s10854-018-9095-z

41. A. Hashim and Q. Hadi, Journal of Inorganic and Organometallic Polymers and Materials, 28, Iss. 4: 1394 (2018); https://doi.org/10.1007/s10904-0180837-4

42. Z. K. Heiba, M. B. Mohamed, and N. G. Imam, Intern. Polymer Processing, 2 (2018).

43. A. Hashim and Z. S. Hamad, Journal of Bionanoscience, 12, No. 4 (2018).

44. M. Aslam, M. Ali Kalyar, and Z. Ali Raza, J. Mater. Sci.: Mater. Electron., (2017); doi:10.1007/s10854-017-7177-y

45. D. Hassan and A. Hashim, Journal of Bionanoscience, 12, Iss. 3 (2018); doi:10.1166/jbns.2018.1533

46. B. H. Rabee and A. Hashim, European Journal of Scientific Research, 60, No. 2: 247 (2011).

47. A. Hashim and A. Hadi, Ukrainian Journal of Physics, 62, No. 11 (2017); doi:10.15407/ujpe62.11.0978

48. D. Hassan and A. Hashim, Journal of Bionanoscience, 12, Iss. 3 (2018); doi:10.1166/jbns.2018.1537

49. K. H. H. Al-Attiyah, A. Hashim, and S. F. Obaid, International Journal of Plastics Technology, 23, No. 1 (2019); https://doi.org/10.1007/s12588-01909228-5

50 A. Hashim and N. Hamid, Journal of Bionanoscience, 12, No. 6 (2018); doi:10.1166/jbns.2018.1591

51. A. Hashim and Z. S. Hamad, Journal of Bionanoscience, 12, No. 4 (2018); doi:10.1166/jbns.2018.1551

52. A. Hashim, I. R. Agool, and K. J. Kadhim, Journal of Materials Science: Materials in Electronics, 29, Iss. 12: 10369 (2018);

https://doi.org/10.1007/s10854-018-9095-z 